during the War he gave much time to testing lenses that were required for military purposes. He observed the solar eclipse of 1914 in Russia, and went to Christmas Island for that of 1922 , but it was cloudy. He has been ten years at the Cape and has made a very careful study of the motions of sun, moon and planets; he has discussed the lunar elements both from the meridian observations and from occultations, of which a great number have been observed. He is also a keen spectroscopist, and has contributed many papers on Nova Pictoris, deducing its distance from the rate of expansion of the nebulous envelopes. The heliometer measures of the planets, inaugurated by Sir David Gill, have been continued, and will shortly be published. Prof. de Sitter testified, in his discussion of the satellites of Jupiter, to the value of the results obtained with that instrument. A reversible transitcircle has been in use at the Cape for many years, of somewhat similar type to the new Greenwich instrument; experience with it will doubtless be of service to Dr. Spencer Jones at Greenwich. He will also find the new Yapp reflecting telescope nearly complete.

\section{Dr. J. Jackson}

DR. J. JACKson, chief assistant at the Royal Observatory, Greenwich, has been appointed H.M. Astronomer at the Cape Observatory in succession to Dr. H. Spencer Jones. Dr. Jackson hails from the University of Glasgow, and went to Trinity College, Cambridge, where he was a scholar from 1909 until 1914, and made researches in dynamical astronomy, particularly the perturbations of Jupiter's eighth satellite. He became chief assistant at the Royal Observatory, Greenwich, in October, 1914, where he took a considerable part in the observing activity of the Observatory. He served with the survey section of the Royal Engineers from December, 1917, to the end of the War. Attention may be directed to Dr. Jackson's work on double star orbits and the determination of hypothetical parallaxes with Mr. Furner; to the very interesting results he obtained from his study of the Shortt clocks; and to his determination of the constant of nutation from observations with the Cookson telescope. During the last seven years, he has co-operated with Dr. Knox Shaw and Mr. Robinson in the reduction of Hornsby's observations at the Radcliffe Observatory, Oxford. Quite recently he has published corrections to the orbit of Mercury for the epoch 1774-98. These results are of special importance as they confirm the motion of the perihelion of the planet, discovered by Leverrier and explained by Einstein. With Prof. F. J. M. Stratton he edited vol. 5 of the collected works of Sir George Darwin. From 1920 until 1927 he was editor of the Observatory magazine, and was secretary of the Royal Astronomical Society from 1923 until 1929.

\section{Boyle Medal of the Royal Dublin Society}

THE council of the Royal Dublin Society at its meeting on December 15 decided, on the recommendation of the Committee of Science and its Industrial
Applications, to confer the Society's Boyle medal on Prof. Paul A. Murphy, professor of plant pathology at University College, Dublin, for his important contributions to plant pathology. Prof. Murphy's researches on the fertilisation, cytology, and life history of the potato blight (Phytophthora infestans), and his investigation on the infection of the new by the old crop, have been at once an important contribution to pure science, and an advance of high economic value. He early recognised the economic importance of mosaic virus, and pointed out the close connexion between the deterioration of new varieties and their infection with virus. $\mathrm{He}$ also established the compound nature of mosaic and recognised the fact that the disease might be transmitted by symptomless carriers. This knowledge has greatly facilitated the finding and propagating of virus-free plants. His researches have also very materially increased our knowledge and means of control of onion mildew (Peronospora Schleideni) and of dry rot in swedes (Phoma lingam).

\section{Native Lands in Kenya}

ON December 20 question was raised in the House of Commons by Sir R. Hamilton as to the situation which has arisen in Kenya in regard to native rights in the land and the leases which are to be granted by the Crown for mineral development in the new goldfield in the district of Kakamega and elsewhere. Certain amendments to the Native Lands Trust Ordinance have been embodied in a Bill which was read for a second time in the Legislative Council of Kenya on December 21. Under these amendments, it is proposed to exclude temporarily from a native reserve, land leased for mineral development, without the provision of an equivalent area of land in exchange and without the requirement of notice to the local native council concerned. Sir R. Hamilton asked whether these proposals were made with the approval of the Secretary of State for the Colonies, and further, whether the amendment of the Native Lands Trust Ordinance had been considered by the Morris-Carter Commission. In his reply, Sir P. Cunliffe-Lister stated that not only had the provisions of the Bill been agreed to both by the Morris-Carter Commission and by the Central Lands Trust Board, but that he was satisfied that the arrangements for compensation and consultation provided ample safeguards for the interests of the native occupants of the area in question.

ThE Secretary of State justified his approval of the amendments on the ground that they are necessary, as an interim measure to deal with immediate practical difficulties which might operate to retard the development of valuable minerals; while provision has been made for compensation in the form of a money payment. His statement that the development of the goldfield would be for the benefit of the native was repeated by the Chief Native Commissioner when introducing the amendments in the Kenya legislature; but he candidly admitted that they would be unpopular with the natives. That admission was an understatement of the case.

No. 3296, VoL. 130] 